\title{
On the Chalcolithic Plant ECONOMy of THE HÂrŞOVA-TEll SETTLEMENT (ROMANIA): RECENT ARCHAEOBOTANICAL RESULTS
}

\author{
ROMAN HOVSEPYAN, \\ RAMON BUXÓ CAPDEVILA, \\ DRAGOMIR-NICOLAE POPOVICI $\dagger$
}

\begin{abstract}
:
Numerous remains of cultivated plants were recovered from the Boian culture, Gumelniţa culture and Cernavoda culture archaeological sediments of Hârșova-Tell, situated on the right bank of Danube River. The archaeological stratigraphy here represents the Copper Age evolution in this region (Boian, Hamangia, Gumelniţa and Cernavoda I Cultures, $5^{\text {th }}-4^{\text {th }}$ millennia BC). The recent archaeobotanical findings are evidence that agriculture was an important direction of the agrarian economy of the local Chalcolithic populations. The charred and in some cases mineralized archaeocarpological material which was recovered and investigated attests to the cultivation of several cereals and pulses: einkorn (Triticum monococcum), emmer (T. dicoccum), bread wheat (T. aestivum), spelt wheat (T. aestivum ssp. spelta), Timopheev's wheat (Triticum timopheevii), naked barley (Hordeum vulgare var. nudum), lentil (Lens culinaris), bitter vetch (Vicia ervilia), and common pea (Pisum sativum). This assemblage of cultivated cereals and pulses, where hulled wheats, particularly einkorn, and naked barley prevail, is common for the Chalcolithic period of South-Eastern Europe. The abundance of pulses is notable, as the cultivation of pulses drops somewhat in this period in the Near East and the Caucasus. In addition to the cultivation of cereals and pulses, viticulture (or use of wild grape) was practiced. Edible fruits, nuts and seeds (maybe herbs as well?) also were gathered and consumed.
\end{abstract}

\section{Rezumat: DesPre eCONOMia VEGETAlă CALCOLITICĂ ÎN AŞEZAREA DE TIP TELL DE LA HÂrŞOVA (ROMÂNIA): REZULTATE ARHEOBOTANICE RECENTE}

Numeroase resturi de plante cultivate au fost recuperate din sedimentele arheologice aparţinând culturilor Boian, Numeroase resturi de plante cultivate au fost recuperate din sedimentele arheologice aparținând culturilor Boian, Gumelniţa și Cernavodă de la Hârş̧ova-tell, situat pe malul drept al fluviului Dunărea. Stratigrafia arheologică de aici reprezintă evoluţia Epocii cuprului din această regiune (culturile Boian, Hamangia, Gumelniţa şi Cernavodă I, mileniile V - IV BC). Descoperirile arheobotanice recente sunt dovada faptului că agricultura a fost o direcţie importantă a economiei agrare a populaţiei calcolitice locale. Materialul arheocarpologic ars şi, în unele cazuri, mineralizat, care a fost recuperat şi investigat, atestă cultivarea câtorva cereale şi leguminoase: alac (Triticum monococcum), emmer cultivat (T. dicoccum), grâu comun (T. aestivum), alac spelt (T. aestivum ssp. spelta), grâu Timopheev (Triticum timopheevii), orz nud (Hordeum vulgare var. nudum), linte (Lens culinaris), măzăriche (Vicia ervilia) și mazăre comună (Pisum sativum). Această asociere de cereale și leguminoase cultivate, în care predomină grâul decorticat, în special alacul, și orzul nud, este comună pentru perioada calcolitică din sud-estul Europei. O abundență constantă a legumelor este notabilă, deoarece cultivarea leguminoaselor scade într-o oarecare măsură, în această perioadă, în Orientul Apropiat și în Caucaz. Pe lângă cultivarea cerealelor și a legumelor, a fost practicată viticultura (sau utilizarea strugurilor sălbatici). Fructele, nucile și semințele comestibile (poate și ierburile?), de asemenea, au fost colectate şi consumate.

KEYwORDS: archaeobotany, Romania, Boian, Gumelniţa, Cernavodă, Chalcolithic, einkorn.

CUVINTE CHEIE: archeobotanică, România, Boian, Gumelniţa, Cernavodă, Calcolitic, alac. 


\section{Introduction}

The archaeological site of Hârşova-Tell is in the south-eastern part of the Hârşova city, on the right bank of Danube River in SE Romania (N 4440'53.02”, E 2757'15.50”, $12 \mathrm{~m}$ a.s.1.). It is the largest tell currently investigated in Romania. The preserved size of the tell is ca. $200 \times 60 \mathrm{~m}$ at its base (Fig. 1, 2). The southern parts of the tell were partly destroyed by the river. The rest of the site was affected by the Roman, medieval/Ottoman and modern human activities. Now the site is covered near entirely by buildings and private yards. The archaeological stratigraphy of the site has more than $12 \mathrm{~m}$ thickness in its central part. The Copper Age is the most representative period for the human occupation of the site and it consists of the Boian (the first half of the $5^{\text {th }}$ millennium B.C.), Gumelniţa (the second half of the $5^{\text {th }}$ millennium B.C.) and Cernavodă I cultures (beginning of $4^{\text {th }}$ millennium B.C.). The surrounding landscape of the site is also strongly affected by human activity; nowadays, the natural vegetation of the riverbank where the site is situated is represented by steppe, where wild grasses (Poaceae) predominate. Meanwhile, the opposite bank, which is somewhat protected from human activity by the river, is covered by riparian forests, where poplar and willow are predominating.

Archaeological excavations at the Hârşova-Tell site started in 1961, conducted by D. Galbenu' ${ }^{1}$, and continued to the present day with some interruptions. The first excavations (a test trench in the central part of the tell) evinced the existence of archaeological remains attributed to the last three phases of the Boian cultural evolution and two of the three stages of the Gumelniţa culture's evolution (Gumelniţa A1 and A2). Starting in 1993, the excavation (ca. $400 \mathrm{~m}^{2}$ ) strategy changed (director of excavations was Dr. Dragomir-Nicolae Popovici ${ }^{2}$ ) to permit a better understanding of the evolution of this exceptional site with a very complicated stratigraphy. It allowed the testing of the informational content of different types of the discovered stratigraphic units (inside or outside dwellings and occupations (marked as US), refuse from different fire contexts, etc.), allowing the elaboration of a specific sampling strategy appropriate for every discipline involved in the multidisciplinary research. The space of the settlement has been organized with buildings of the same dimensions built one after another and having passageways between, which demonstrates the presence of a highly organized community ${ }^{3}$.

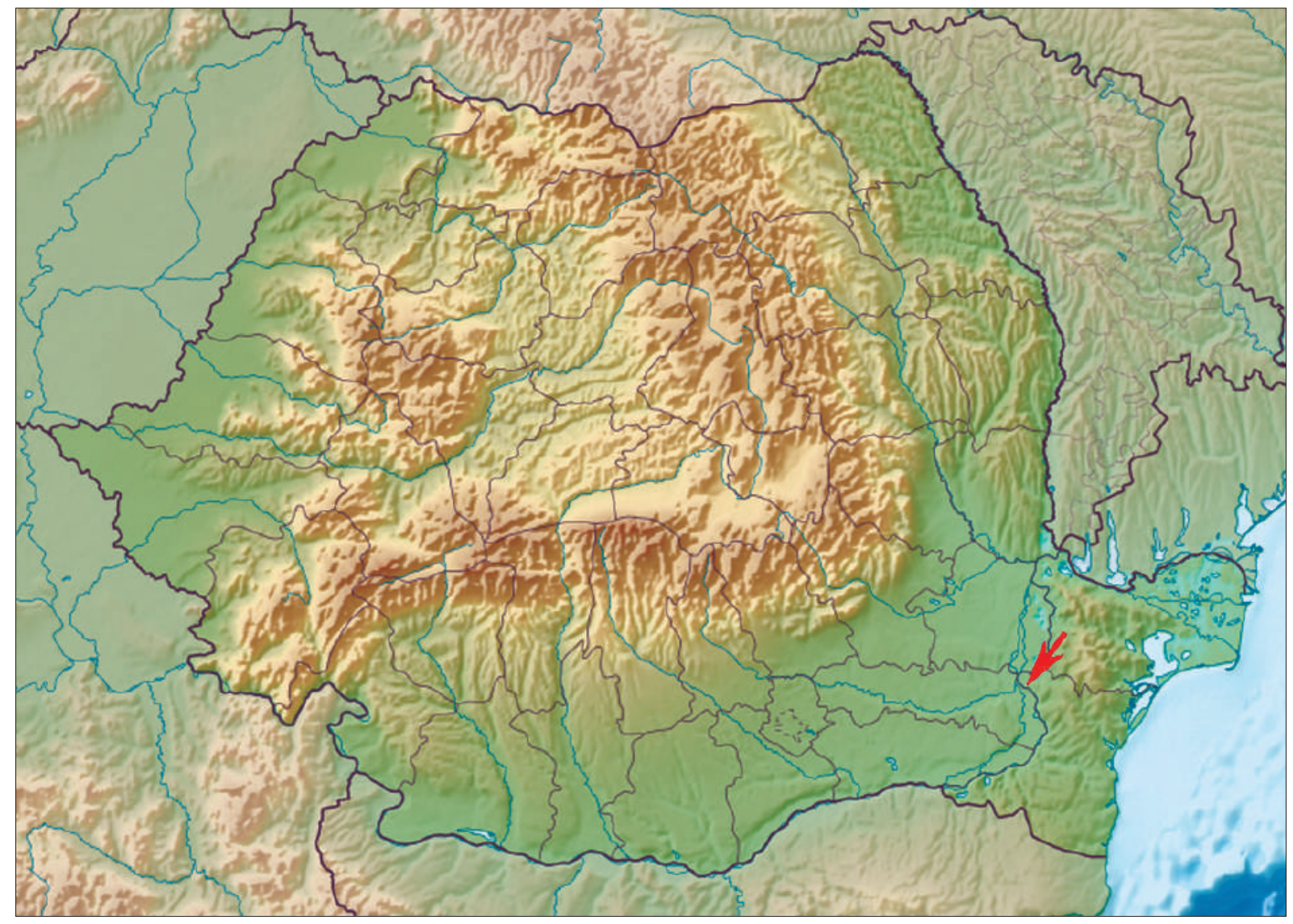

Figure 1. Location of Hârşova-Tell on the map of Romania.

\footnotetext{
Galbenu 1962

2 Popovici et al. 1998-2000, 2001, 2014.

Popovici et al. 2001, 2014.
} 


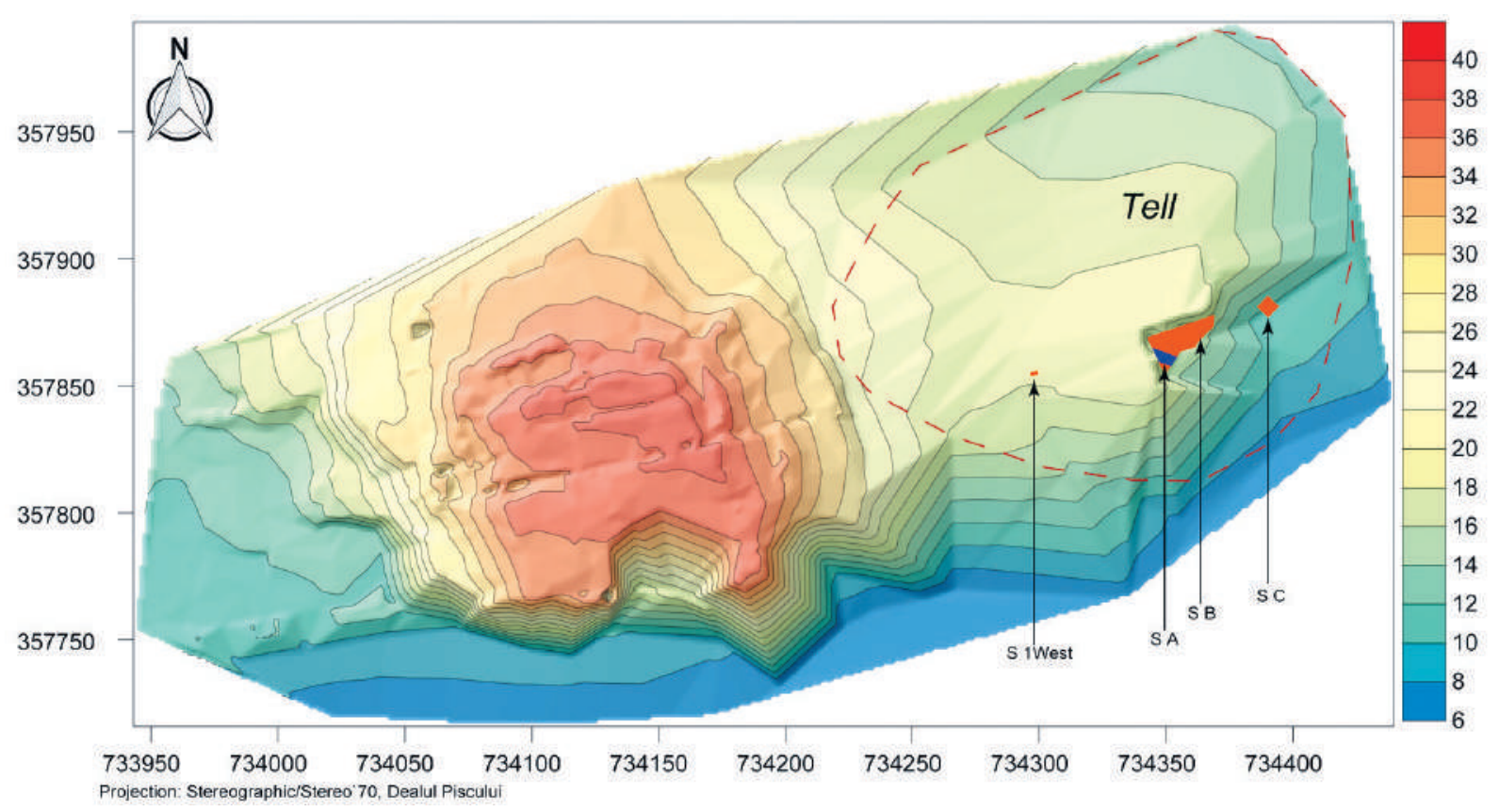

Figure 2. Excavation plan of the archaeological site of Hârşova-Tell (by Mihai Florea).

Starting from 2013, a small surface excavation (ca. $60 \mathrm{~m}^{2}$ ) was conducted in the central-eastern part of the tell and three test trenches were dedicated to the Boian occupational sequences (ca. $3.4 \mathrm{~m}$ in its total stratigraphical extent) in the lower part of the tell, which is, as of now, the most complete for the evolution of the Boian culture in that part of Romania (Fig. 2 - SC). Archaeological structures like dwellings, hearths, and waste throwing areas were uncovered and investigated offering important information about the character of the Boian habitation sequences and palaeoeconomy in that area of the tell. Our current study aimed to reveal information about agriculture and plant-gathering practices of the Boian, Gumelniţa, and Cernavodă I culture communities of the settlement and thus complete our understanding of these communities' economies.

\section{Methods}

Material from the recent years and some samples remained from the previous excavations were studied. The studies were performed on the plant carpological remains preserved in the archaeological sediments. The Boian, Gumelniţa, and Cernavodă I cultural layers of the Hârşova-Tell site were investigated. The plant remains were recovered using standard flotation and wet-sieving techniques, sometimes by the co-application of both methods. Here we would like to mention the importance of the co-application of the flotation and wet-sieving methods, because, for example in the case of bitter vetch (from stratigraphical unit 30045; Fig. 4:19), the seeds were not floating at all, but settled down and were recovered only by the wet-sieving. The identification of the recovered material was done using the corresponding references ${ }^{4}$. During the investigations in the recent years, 1460 units of carpological material were recovered from the Boian culture layers of the site as a result of 19 processed samples with 330 liters of total volume (Tab. 1). Alongside the regular dispersed archaeobotanical material, large hoards of cultivated plants (with thousands of seeds) also recovered from the Gumelniţa culture sediments and studied (Tab. 2). Archaeobotanical material from the Cernavodă I culture is the fewest but gives valuable information about this occupational phase of the site (Tab. 3).

\footnotetext{
$\overline{4}$ Zohary et al. 2012; Jacomet 2006.
} 
Table 1. Archaeocarpological material from the Boian culture layers of Hârşova-Tell (excavations of 2013 and 2016, Zone SC/pP, Sector 20).

\begin{tabular}{|c|c|c|c|c|c|c|c|c|}
\hline \multicolumn{3}{|l|}{ Stratigraphical unit (US) } & & 20170 & 20246 & 20247 & 20646 & 20863 \\
\hline \multicolumn{3}{|l|}{ Habitation Structure (SL) } & & & - & & 109 & - \\
\hline \multicolumn{2}{|l|}{ Complex $(\mathbf{C})$} & & & & 2065 & & - & - \\
\hline \multicolumn{3}{|c|}{\begin{tabular}{|l|l} 
Sediments volume (liter) & \\
\end{tabular}} & 333.0 & 92.5 & 188.0 & 46.0 & 3.5 & 3.0 \\
\hline \multicolumn{3}{|c|}{ Concentration of all carpological material (unit/liter) } & 4.4 & 2.7 & 2.5 & 3.6 & 163.4 & 5.7 \\
\hline \multicolumn{3}{|c|}{ Concentration of cultivated plants' carpological material (unit/liter) } & 4.3 & 2.6 & 2.4 & 3.5 & 160.6 & 4.7 \\
\hline Plant taxon & Organ & Preservation & 1476 & 253 & 471 & 166 & 572 & 17 \\
\hline Triticeae gen. spp. & grains fragm. & charred & 392 & 98 & 156 & 82 & 49 & 7 \\
\hline Triticeae gen. spp. & internodes & - & 1 & - & 1 & - & - & - \\
\hline \multirow[t]{2}{*}{ Wheat-Barley proportion } & & (everything) & $84.8 \%$ & $26.2 \%$ & $87.0 \%$ & $76.0 \%$ & $100 \%$ & $14.3 \%$ \\
\hline & & (only grains) & $82.3 \%$ & $24.4 \%$ & $77.0 \%$ & $64.7 \%$ & $100 \%$ & $16.7 \%$ \\
\hline cf. Triticum spp. & grains & charred & 21 & 4 & 15 & 2 & - & - \\
\hline Triticum spp. & - & - & 90 & 13 & 61 & 11 & 5 & - \\
\hline Triticum aestivum/turgidum & - & - & 1 & - & - & - & 1 & - \\
\hline Triticum cf. aestivum ssp. spelta & - & - & 3 & 1 & 2 & - & - & - \\
\hline Triticum aestivum ssp. spelta & - & - & 2 & - & - & 2 & - & - \\
\hline Triticum cf. dicoccum & - & - & 67 & 2 & 9 & 1 & 55 & - \\
\hline Triticum dicoccum & - & - & 100 & 2 & 4 & - & 94 & - \\
\hline $\begin{array}{l}\text { Triticum monococcum/ dicoccum/ } \\
\text { timopheevii }\end{array}$ & - & - & 241 & 3 & 18 & 11 & 209 & - \\
\hline Triticum timopheevii/dicoccum & - & - & 22 & - & 2 & - & 20 & - \\
\hline Triticum monococcum/timopheevii & - & - & 70 & 2 & 13 & 3 & 52 & - \\
\hline Triticum monococcum & - & - & 32 & 2 & - & 2 & 27 & 1 \\
\hline Triticum cf timopheevii & - & - & 26 & 1 & - & 1 & 24 & - \\
\hline Triticum timopheevii & - & - & 25 & - & - & - & 25 & - \\
\hline Triticum cf. dicoccum & spikelet bases & charred & 9 & - & 7 & 2 & - & - \\
\hline Triticum dicoccum & - & - & 2 & - & 1 & 1 & - & - \\
\hline $\begin{array}{l}\text { Triticum monococcum/timopheevii/ } \\
\text { dicoccum }\end{array}$ & - & - & 49 & 3 & 34 & 12 & - & - \\
\hline Triticum timopheevii/dicoccum & - & - & 2 & - & 2 & - & - & - \\
\hline Triticum monococcum/timopheevii & - & - & 28 & - & 25 & 3 & - & - \\
\hline Triticum $\mathrm{cf}$ monococcum & - & - & 8 & - & 8 & - & - & - \\
\hline Triticum monococcum & - & - & 23 & - & 19 & 3 & 1 & - \\
\hline Triticum cf timopheevii & - & - & 15 & - & 12 & 3 & - & - \\
\hline Triticum timopheevii ${ }^{*}$ & - & - & 15 & - & 15 & - & - & - \\
\hline Barley-Wheat proportion & & (only grains) & $17.7 \%$ & $75.6 \%$ & $23.0 \%$ & $35.3 \%$ & $0 \%$ & $83.3 \%$ \\
\hline cf. Hordeum vulgare & grains & charred & 40 & 17 & 16 & 6 & - & 1 \\
\hline Hordeum vulgare* & - & - & 84 & 52 & 20 & 12 & - & - \\
\hline Hordeum vulgare cf. var. nudum & - & - & 6 & 6 & - & - & - & - \\
\hline \multirow{2}{*}{ Hordeum vulgare var. nudum* } & - & - & 9 & 8 & 1 & - & - & 2 \\
\hline & $\begin{array}{l}\text { triplet middle } \\
\text { grains }\end{array}$ & - & 10 & 10 & - & & - & - \\
\hline $\begin{array}{l}\text { Hordeum vulgare ssp. vulgare convar. } \\
\text { coeleste* }\end{array}$ & $\begin{array}{l}\text { triplet right } \\
\text { grains }\end{array}$ & - & 2 & - & - & - & - & 2 \\
\hline Hordeum vulgare & internodes & - & 1 & - & - & - & - & 1 \\
\hline Pulses-Cereals proportion & & $\begin{array}{l}\text { (only seeds \& } \\
\text { grains) }\end{array}$ & $2.4 \%$ & $7.3 \%$ & $2.6 \%$ & $2.9 \%$ & $0 \%$ & $0 \%$ \\
\hline Fabaceae: Vicieae gen. sp. (cult.) & seeds & charred & 9 & 2 & 5 & 2 & - & - \\
\hline Vicieae: cf. Pisum sp. & - & - & 7 & 5 & 1 & 1 & - & - \\
\hline Pisum sativum & - & - & 1 & 1 & - & - & - & - \\
\hline Vicieae: cf. Vicia sp. & - & - & 2 & 2 & - & - & - & - \\
\hline Vicieae: cf. Vicia ervilia* & - & - & 5 & 3 & 2 & - & - & - \\
\hline Vicieae: cf. Lens sp. & - & - & 3 & 2 & 1 & - & - & - \\
\hline Lens culinaris* & - & - & 4 & 3 & - & 1 & - & - \\
\hline \multicolumn{3}{|l|}{ Wild edible fruits, berries, large seeds } & $0.5 \%$ & $1.2 \%$ & $0.9 \%$ & $0.7 \%$ & $0 \%$ & $\mathbf{0 \%}$ \\
\hline Trapa natans $*$ & nut fragments & charred & 6 & 3 & 2 & 1 & - & - \\
\hline Cornus mas* & nutstones & charred & 1 & - & 1 & - & - & - \\
\hline Weeds and wild herbs & & & $3.2 \%$ & $3.2 \%$ & $5.2 \%$ & $2.8 \%$ & $1.8 \%$ & $17.6 \%$ \\
\hline $\begin{array}{l}\text { Buglossoides arvensis (= Lithospermum } \\
\text { arvense) }\end{array}$ & nutlet & biomineralized & 1 & - & - & - & - & 1 \\
\hline Lithospermum purpurocaeruleum* & nutlet & biomineralized & 1 & 1 & - & - & - & - \\
\hline Hordeum $s p$. (wild/weed)* & grains & charred & 2 & 1 & - & - & 1 & - \\
\hline Asperugo procumbens $*$ & erems & biomineralized & 1 & - & - & - & 1 & - \\
\hline cf. Lamiaceae gen. sp.* & nutlets & biomineralized & 1 & - & - & - & 1 & - \\
\hline cf. Cyperaceae gen. sp. ${ }^{*}$ & nutlets & charred & 3 & 1 & 2 & - & - & - \\
\hline $\begin{array}{l}\text { Amaranthaceae /Chenopodiaceae } \\
\text { gen.spp. }\end{array}$ & seeds & charred & 2 & - & - & - & 2 & - \\
\hline \multirow[t]{2}{*}{ cf. Chenopodium sp. } & seeds & mineralized & 1 & - & 1 & - & - & - \\
\hline & - & charred & 2 & - & 2 & - & - & - \\
\hline Chenopodium sp. * & - & charred & 6 & - & 5 & 1 & - & - \\
\hline Unidentified species & seeds & charred & 23 & 5 & 8 & 3 & 5 & 2 \\
\hline
\end{tabular}

Notes: Sediment samples from US 20170 and US 20247 were taken from ash lenses. Seed material present in ash lenses of US 20247 apparently spread also into overlying US 20246.

* - New for the Boian culture of Hârşova-Tell 


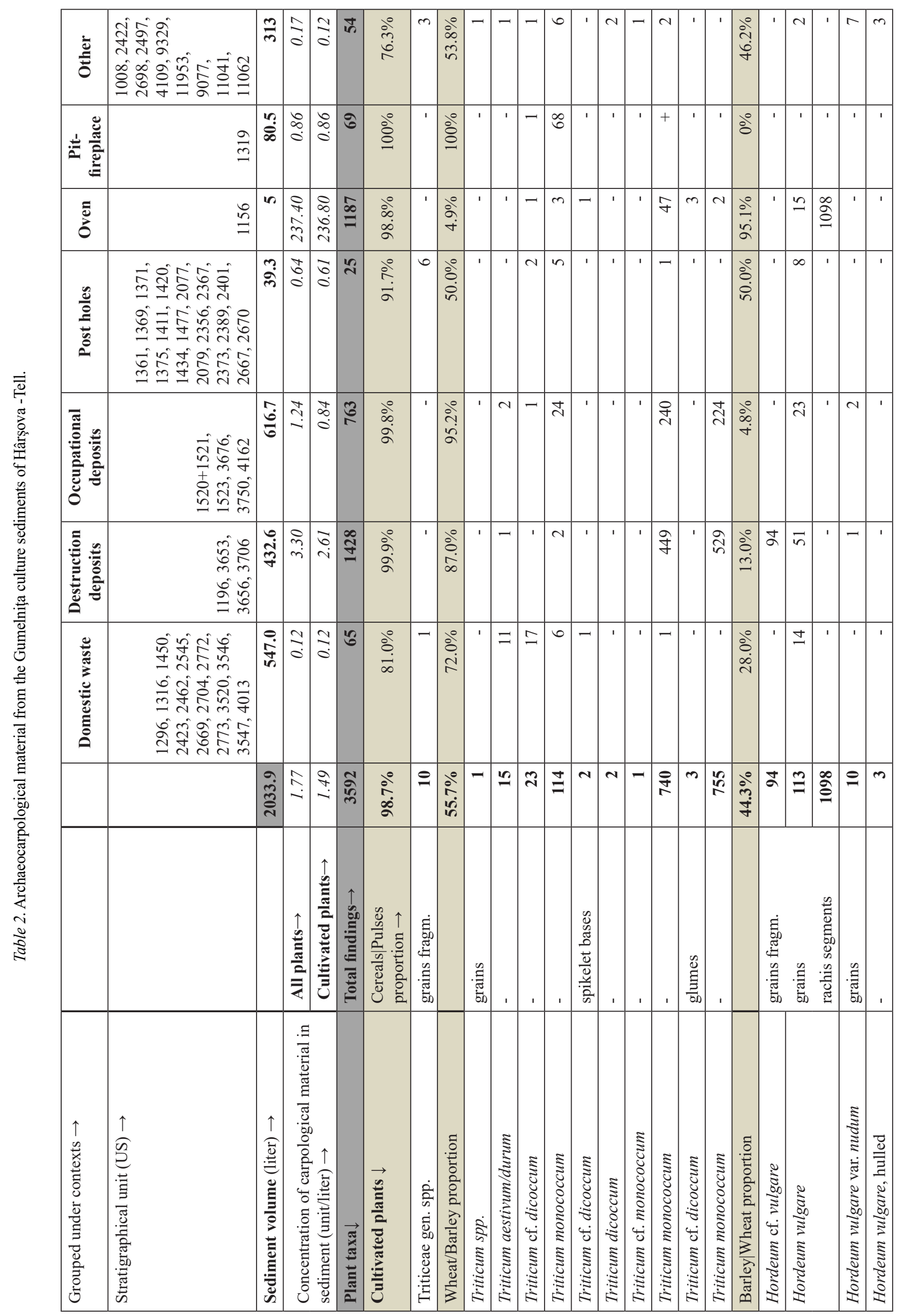




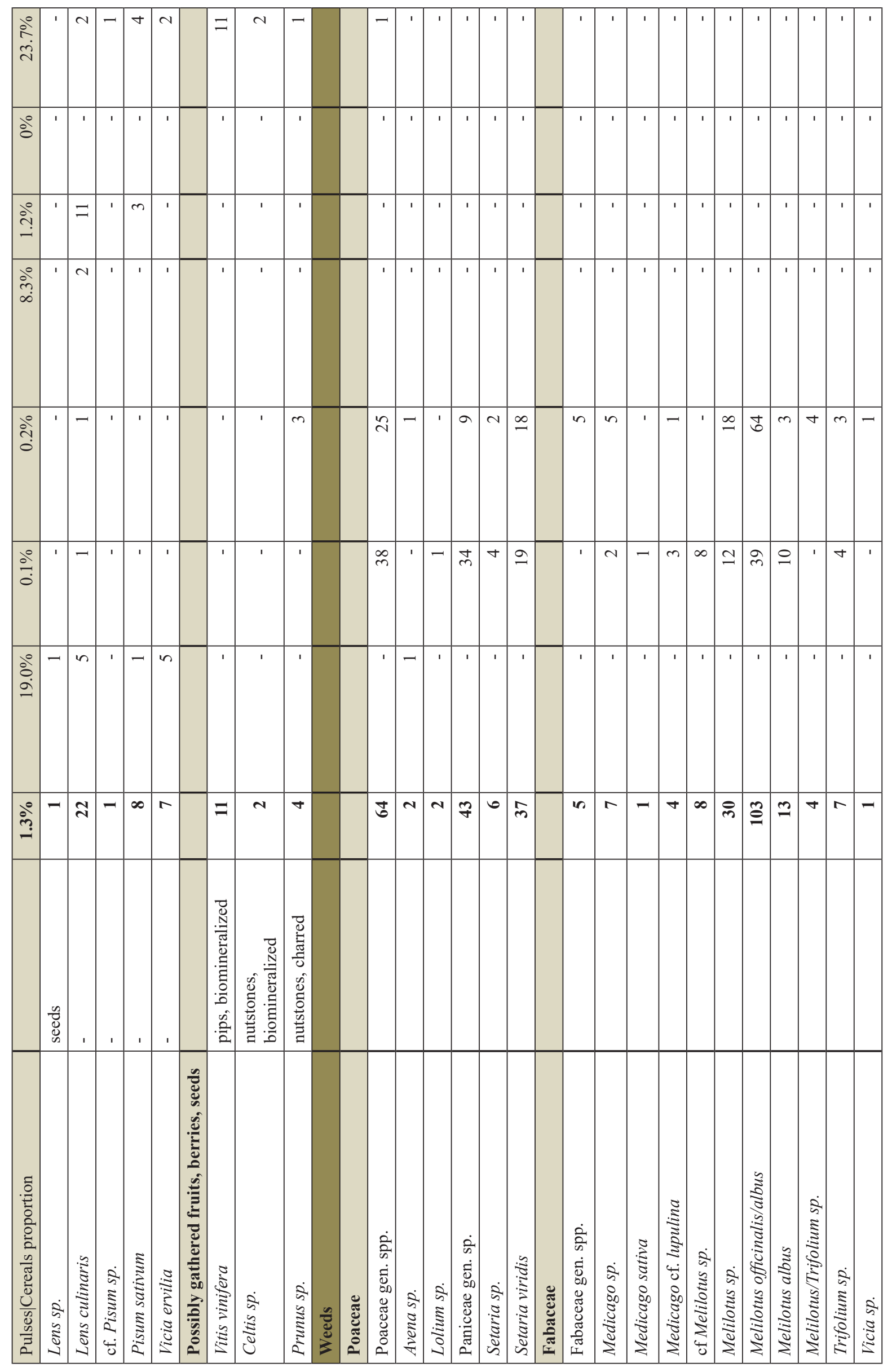




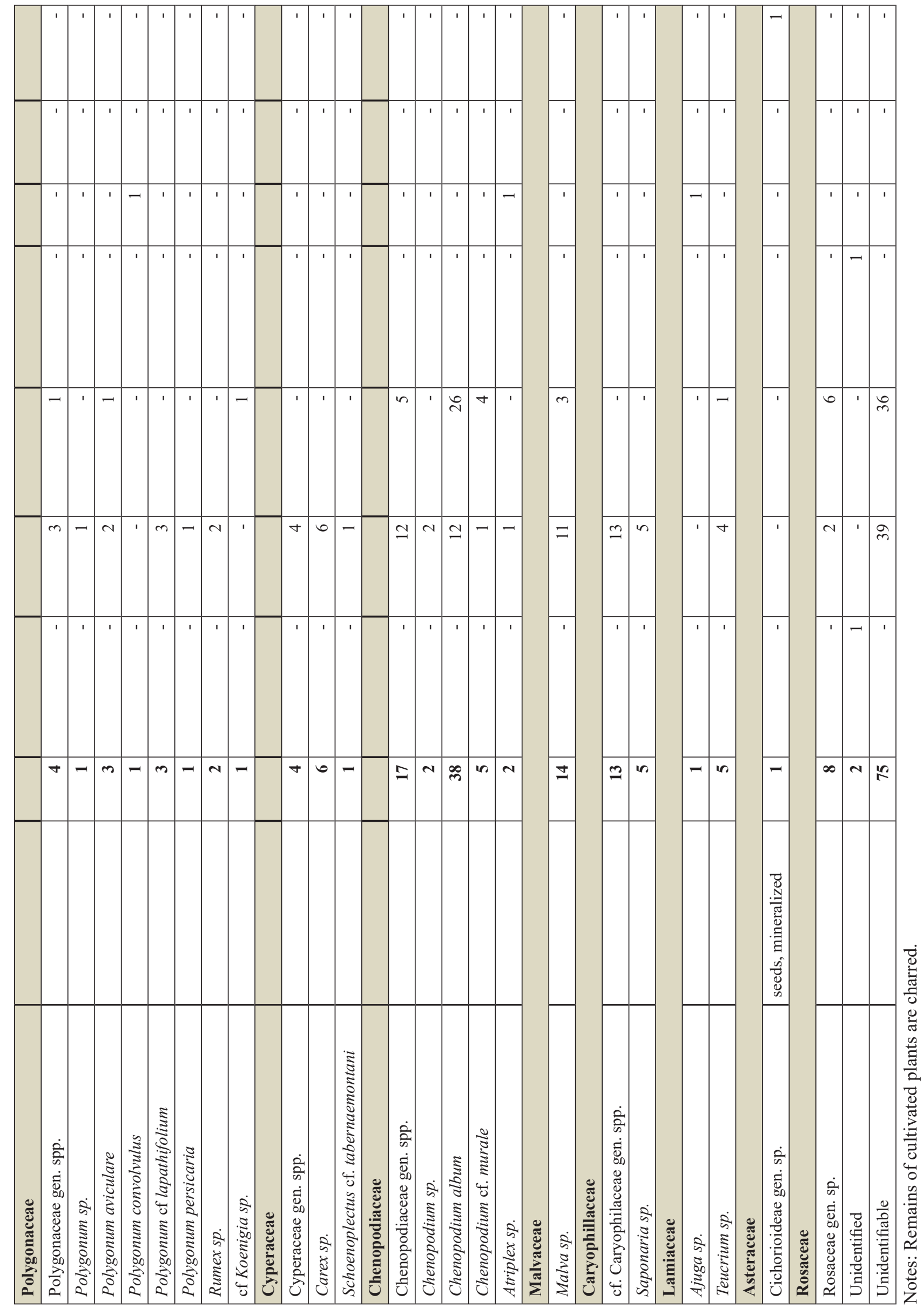


Table 3. Archaeocarpological material from the Cernavodă I culture layers of Hârşova-Tell.

\begin{tabular}{|c|c|c|c|c|c|c|c|}
\hline \multicolumn{3}{|l|}{ Stratigraphical units (US) } & $\begin{array}{c}3501,3502,3507, \\
3510,3511,3513, \\
3516,3517,3518, \\
3551\end{array}$ & $\begin{array}{l}1709 / 1740 \\
3500,3508\end{array}$ & $\begin{array}{l}3533 \\
3535\end{array}$ & 3543 & 3503 \\
\hline \multicolumn{2}{|l|}{ Context } & Total & domestic waste & $\begin{array}{c}\text { destruction } \\
\text { layer }\end{array}$ & fireplace & pit fill & post hole \\
\hline \multicolumn{2}{|c|}{ Volume of proceeded sediments (liter) } & 1157.9 & 378.2 & 56.7 & 16.0 & 705.0 & 2.0 \\
\hline \multirow{2}{*}{$\begin{array}{l}\text { Concentration of } \\
\text { carpological material in } \\
\text { sediments (unit/liter) }\end{array}$} & All plants & 0.19 & 0.34 & 0.25 & 0.25 & 0.09 & 2.00 \\
\hline & $\begin{array}{l}\text { Cultivated } \\
\text { plants }\end{array}$ & 0.17 & 0.32 & 0.25 & 0.13 & 0.09 & 2.00 \\
\hline Triticeae gen. sp. & $\begin{array}{l}\text { grains } \\
\text { fragments }\end{array}$ & 7 & 6 & - & 1 & - & - \\
\hline Hordeum vulgare & grains & 27 & 10 & - & - & 17 & - \\
\hline Triticum aestivum/durum & grains & 122 & 90 & 3 & - & 26 & 3 \\
\hline \multirow{2}{*}{ Triticum dicoccum } & grains & 10 & 5 & 2 & - & 3 & - \\
\hline & spikelet base & 1 & - & 1 & - & - & - \\
\hline \multirow[b]{2}{*}{ Triticum monocoсcum } & grains & 20 & 8 & 5 & 1 & 5 & 1 \\
\hline & $\begin{array}{l}\text { spikelet } \\
\text { bases }\end{array}$ & 3 & - & 3 & - & - & - \\
\hline Lens culinaris & seeds & 10 & 1 & - & - & 9 & - \\
\hline Paniceae gen. spp. (wild) & grains & 6 & 3 & - & 1 & 2 & - \\
\hline Unidentified & - & 3 & 2 & - & - & 1 & - \\
\hline
\end{tabular}

\section{Results}

The majority of the archaeocarpological findings from the processed sediments coming from all the abovementioned three cultures belonged to cultivated plants (Tab. 1-4).

\section{The Boian culture archaeobotanical findings}

The following cultivated plants were recorded from the Boian culture sediments (listed according to the number of findings): einkorn (Triticum monococcum, Fig. 4: 1-6), emmer (Triticum dicoccum, Fig. 4: 7-12), naked barley (Hordeum vulgare var. nudum, Fig. 4: 14-18), spelt wheat (Triticum aestivum ssp. spelta, Fig. 4: 13), lentil (Lens culinaris, Fig. 4: 21), bitter vetch (Vicia ervilia; Fig. 4: 19) and pea (Pisum sativum, Fig. 4: 20). Along with the regular einkorn (Triticum monococcum), Timopheev's wheat (Triticum timopheevii) is present as well (Fig. 4:4). There are also poorly preserved specimens and specimens with intermediate morphological and anatomical features, the taxonomical attribution of which it was not possible to identify up to a certain taxonomic level; those remains are comparably large and in all probability belong to the above-mentioned cultivated plants (Triticeae gen. spp., Vicieae gen. sp., etc; Tab. 1). Remarkably, all comparably well-preserved and identifiable wheat (Triticum) groups recovered belong to hulled varieties. On the contrary, there are no results attesting to the presence of hulled varieties of barley in the studied sediments, while naked grains are numerous. Such a situation is not unusual as einkorn is one of the most frequent cultigens of Neolithic-Chalcolithic Europe ${ }^{5}$. The proportions of wheat and barley are $85.2 \%$ to $14.8 \%$ in the studied Boian culture sediments, and, if future findings will not change these proportions, it may attest to the secondary role of barley for the Boian population of Hârşova. It worth mentioning, that the proportions of the cereals do vary from sample to sample quite intensely. The barley grains were completely absent in some samples, while in others the wheat grains are absent or the proportions are very polarized. This is indirect evidence that these cereals were cultivated separately by the Boian culture communities of Hârşova.

The essential part of the cereal grains (more than 550) recovered from the Boian cultural sediments of the Hârşova-Tell settlement comes from the surface of a clay floor of a secondary structure built next to a dwelling (US 20646, SL 109; sector 20 of zone SC/PP; Tab. 1, Fig. 2). The grains were concentrated in the southwestern corner of the room (squares D3 and C3D3; e.g. Fig. 4: 1-4, 7-12). Both grains and other remains of the spikelets were recovered. Many of the recovered emmer grains were still attached in the way as they were in the spikelets. These

\footnotetext{
$\overline{5}$ Zohary et al. 2012 .
} 
attest that unprocessed yield was stored and maybe also processed in this structure. The floor (US 20646) from where the grains were found was the last floor of this structure, after which the dwelling was destroyed by fire ${ }^{6}$.

The other three locations investigated (US 20246, US 20170 and US 20247) were ashy lenses in one complex, which represents a domestic waste area between dwellings. This complex indicates domestic activities with a lot of charcoal, bones, shells, fragments of ceramics, etc. US 20170 and US 20247 were situated at the same level, but without connection and US 20246 was formed after these two (stratigraphically it is a later formation; Fig. 2 - SB).

The recovered cultivated pulses quantitatively predominate over the cereals (the average value is $2.1 \%$ ), but in some samples their quantity is critical (20\% and more; Tab. 1$)$.

Wild and weedy plant taxa recorded for the Boian culture layers of Hârşova-Tell include water caltrop (Trapa natans; Fig. 4: 11), cornelian cherry (Cornus mas; Fig. 4: 10), purple gromwell (Lithospermum purpurocaeruleum; Fig. 4: 12), a wild species of barley (Hordeum sp.), madwort (Asperugo procumbens), species of Lamiaceae family and Cyperaceae family (probably Scirpus type), goosefoots (Chenopodium sp.) (Tab. 1). It was not possible to identify even the family attribution of the recovered seeds in some cases, because of their poor preservation (Tab. 1).

The fragmented and charred nuts of Trapa natans and the nutstones of Cornus mas found at the site may suggest that these plants were utilized: the seeds of Trapa enclosed in the nuts and flesh (the exocarp and mesocarp) of the Cornus fruits are edible. A biomineralized nutlet (erem) of Lithospermum purpurocaeruleum found within the site is not complete, but, even in that state, it is visible that the apex and the bottom of the nutlet were trimmed to prepare a bead (Fig. 4: 12). Findings of Lithospermum nutlets in this processed state are not new: it is already known that nutlets of Lithospermum purpurocaeruleum have been used for the preparation of beads in the prehistoric times of Romania (Cucuteni and Gumelniţa cultures) ${ }^{7}$. The other wild plants recorded are common weeds (Hordeum sp., Asperugo procumbens, cf. Lamiaceae, Chenopodium sp.) or hydrophile plants, which attest to the presence of wetlands (cf. Cyperaceae gen. sp., as well as the Trapa). In general, the quantities of wild/weedy plants are low and the dataset consists more generally of cultivated plants.

\section{The Gumelniţa culture archaeobotanical findings}

The assemblage of cultivated plants recorded for the Gumelniţa cultural contexts of Hârşova-Tell generally repeats that associated with the Boian culture (Tab. 1,2). The few observed differences are probably incidental and caused by the differences in the sampling and/or volumes of the processed sediments. The proportion values of pulses (the same taxa recorded for both cultures) in cultivated plants, i.e. cereals and pulses, is between 1-2\% for both, the Boian and Gumelniţa cultures materials (Tab. 1, 2, 4). The proportion of wheat and barley is almost equal for the studied Gumelniţa culture material (55.7\% and 44.3\%, Tab. 2, 4). Few hulled barley grains present here, while they are not recorded yet for the Boian culture layers. As in the case of the Boian culture samples, the einkorn prevails in the Gumelniţa culture material, too. Other plants identified include edible fruits (Prunus, Vitis and Celtis) and wild and weedy plants (species of Ajuga, Avena, Setaria, Lolium, Paniceae tribe and other Poaceae, Atriplex, Polygonum, Rumex, Chenopodium, species of Rosaceae, Saponaria, Scirpus, Carex and other Cyperaceae, Teucrium, Medicago, Melilotus, Trifolium, Vicia).

There are some contexts excavated in Hârşova-Tell, where large concentrations of cultivated plants were recovered. For example, in sequencing stratigraphic units 30034 and 30036 of Test trench $1 \mathrm{~W}$ (excavated in 2014; Fig. 2 - S1 West, Fig. 5, Fig. 3a) several ten thousands grains of charred naked barley (Hordeum vulgare var. nudum) were uncovered on the floor of dwelling no. 302. These two stratigraphical units represent lenses with grains in massive quantities, which were situated on the same floor very close next to each other $(\sim 10 \mathrm{~cm})$, but without a visible relation on the stratigraphic profile. They probably are from the same hoard. Meanwhile, nothing was recovered from the sediments of the overlying (US 30003, 30009, 30012, 30023, 30024) and the underlying stratigraphic units (US 30047), which supports the supposition that the above-mentioned barley accumulations come from one archaeological context and represents a single event (Fig. 3). The bulk of these barley grains in both samples (US 30034 and US30036), which were less distorted from charring, are triplet middle grains, attesting that the hoard mostly or perhaps entirely comes from two-rowed naked barley (Fig. 4: 14, 16, 18). Interestingly, stratigraphical units US 30009, 30012, 30023, 30024, which were situated over this barley hoard, belong to one hearth structure (an oven; C 3002; US 30003 and US 30047 are two different situations, but both represent space between dwellings, common space where people used to throw the domestic waste), but did not contain any carpological material at all but charcoal (Fig. 3b). This is good evidence that the oven was not used to prepare vegetal food when the above-mentioned layers were formed. It may have been used to prepare only animal food during that period, or to heat the dwelling or for other unidentified purposes.

In the same manner, a concentration of bitter vetch (Vicia ervilia) seeds (around 3460 seeds counted) was recovered from a floor (US 30045) of a non-burnt dwelling (SL 304, Test trench 1 W excavated in 2014; Fig. 2 - S1 West, Fig.

\footnotetext{
6 Popovici 2010.

7 Cârciumaru 1996; Marinescu-Bîlcu, Cârciumaru 1992.
} 


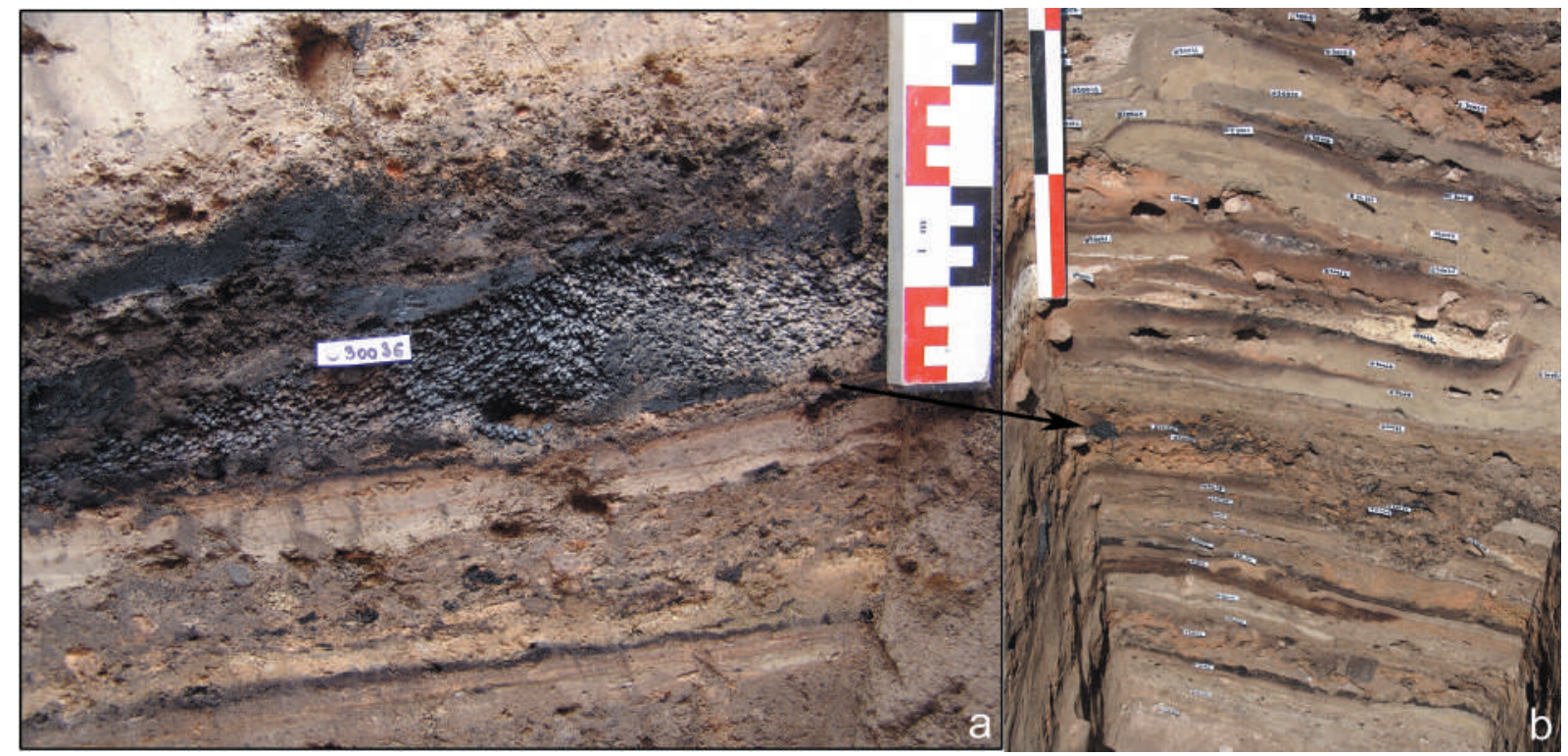

Figure 3. Hoard of charred barley grains in dwelling N302 of Hârşova-Tell and its stratigraphical position on the east profile of test trench I West (excavation of 2014; by D.-N. Popovici).

3b, Fig. 4: 19). Another little hoard of pulses, though more poorly preserved and comprising more than 100 charred seeds probably from pea (cf. Pisum sp.), was uncovered from a destruction layer of a burnt building (square D5 of stratigraphic unit 9329 in SL 19 of Sector 7 Zone SB, exc. of 2002; Fig. 2 - SB). The examination of the content of vessel N2 (assemblage 3) from the same layer revealed thousands of charred grains of emmer. Possibly these seeds were put in the fire intentionally as an offering. Another large concentration of cultivated plants' remnants was recorded for oven US 1156 (Tab. 2): 92\% of 1,188 findings from this oven were barley triplet bases that with other remnants of the threshing waste were probably used as fuel.

Sometimes accumulations of weeds, presumably collected by insects, also can be encountered at excavations, e.g. the concentration of more than one thousand biomineralized nutlets of field gromwell (Buglossoides arvensis; location of findings: L12 (d), $\square$ K4, SB, exc. in 1991; Fig. 2 - SB).

\section{The Cernavodă I culture archaeobotanical findings}

Mostly remains of cultivated plants were found from the samples belonging to the Cernavodă I culture. They repeat the taxa recorded for the Boian and Gumelniţa cultures (from the most common to less): naked wheat (Triticum aestivum/durum), barley (Hordeum vulgare), einkorn (Triticum monococcum), emmer (T. dicoccum), and lentil (Lens culinaris). In addition, some seeds of plants from the Paniceae subfamily were recovered (probably wild species; Tab. 3).

\section{Discussion}

There are similar findings from the previous archaeobotanical investigations of Hârşova-Tell. The first archaeobotanical investigations at the settlement of Hârşova-Tell were carried out by Marin Cârciumaru, who studied the Boian culture material from archaeological campaigns in 1961 and 1988, and the Cernavodă I culture material from the campaign of 1986. The following cultivated plants were identified by him for the Boian culture: Triticum monococcum, T. dicoccum, T. aestivum ssp. spelta, T. cf. aestivum, Pisum sativum; and for the Cernavodă I culture: Quercus sp. ${ }^{8}$

Felicia Monah worked on archaeobotanical materials from the excavations of 1998 and the earlier years (but after 1995$)^{9}$ as well as on some samples from the excavations of $2000^{10}$. The following taxa of cultivated plants were recorded by her for the Gumelniţa culture (Complex 521): Triticum aestivum, T. monococcum, T. dicoccum, Hordeum vulgare, Secale cereale, Vicia ervilia, Lens culinaris, Pisum sativum, Vicia sp., Vitis vinifera, plus some wild plants: Vitis sylvestris, Trapa natans, Chenopodium album, Sambucus nigra, Echium sp., Crambe tatarica. ${ }^{11}$

\footnotetext{
8 Cârciumaru 1996

9 Monah 2000.

10 Monah 2007a.

11 Monah 2000.
} 

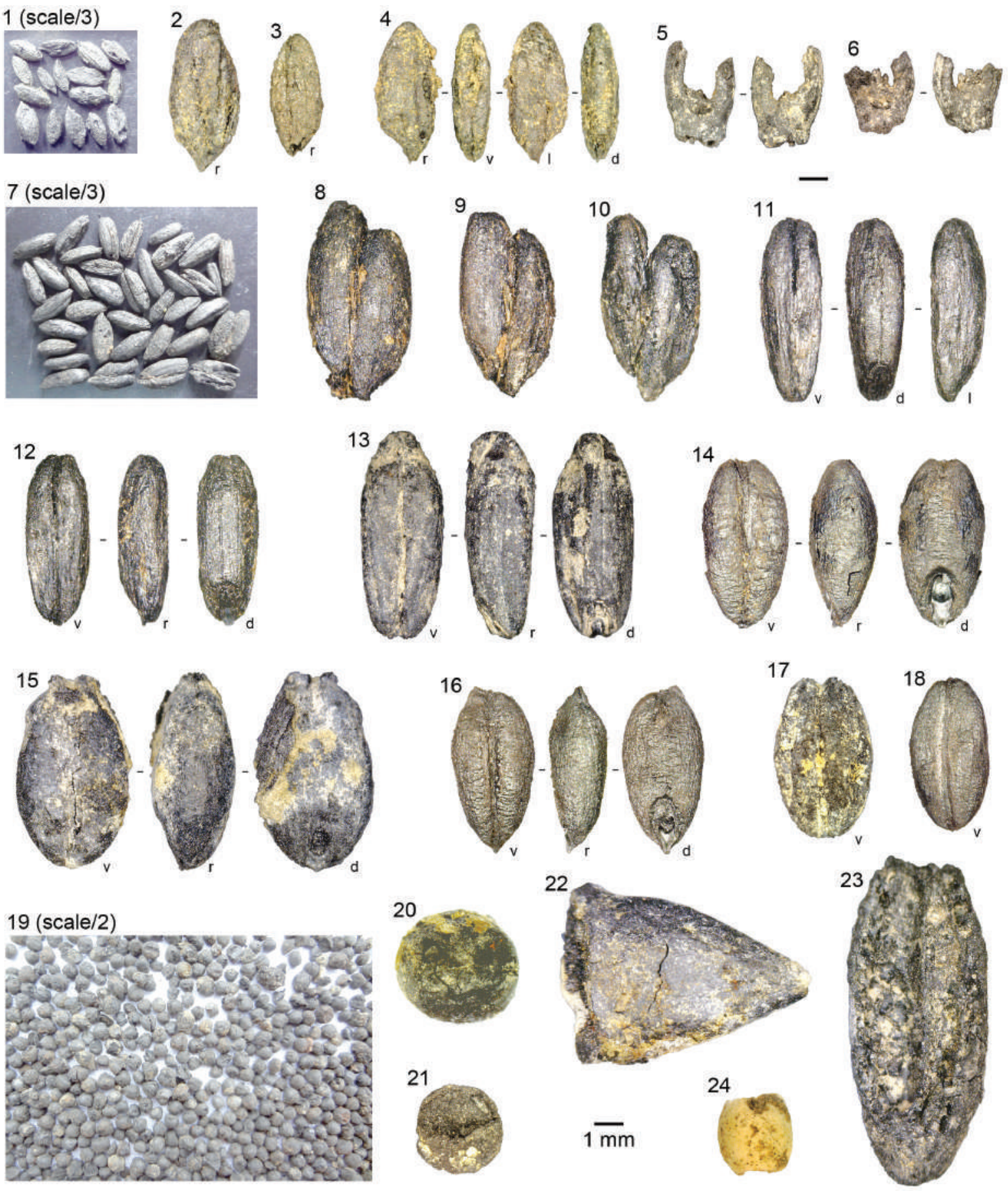

Figure 4. Archaeobotanical findings from the Boian culture and Gumelniţa culture contexts of the Hârşova-Tell archaeological site (by R. Hovsepyan). 1-4 - charred grains of einkorns, 2-3 - single grained einkorn (Triticum monococcum), 4 - Timopheev's wheat (Triticum timopheevii), 5 - spikelet base of einkorn, 6 - spikelet base of Timofeev's wheat, 7-12 - charred grains of emmer (Triticum dicoccum), 8-10 - grains from the same spikelets, which stayed attached after glumes of spikelets were gone, 13 - charred grain of spelta wheat (Triticum aesticum ssp. spelta),14-18 - charred grains of naked barley (Hordeum vulgare var. nudum), 19 - charred seeds of bitter vetch (Vicia ervilia), 20 - charred seed of common pea (Pisum sativum), 21 - charred seed of lentil (Lens culinaris), 22 - charred part of water caltrop (Trapa natans) nut, 23 - charred nutstone of cornelian cherry (Cornus mas), 24 - biomineralized nutlet of Lithospermum purpurocaeruleum graven on the top and in the bottom to make a bead. Cultural belonging: 1-13, 15, 17, 20-24 - Boian (exc. 2013), 14, 16, 18-19 - Gumelniţa (exc. 2014) (Location of specimens: 1-4 - SC/pP, St. 20, US 20646, SL 109, D3; 5-6 - SC pP, St. 20, US 20246, C 2065, B3; 7-12 - SC/pP, St. 20, US 20646, SL 109, C3-D3; 13 - SC/pP, St. 20, US 20247, C 2065, C1; 14, 16, 18 - S 1 V, US 30036 ; 15, 17, 20-22, 24 - SC/pP, St. 20, US 20170, C 2065, D1; 19 - S 1 V, US 30045; 23 - SC/pP, St. 20, US 20246, C 2065, A1). 


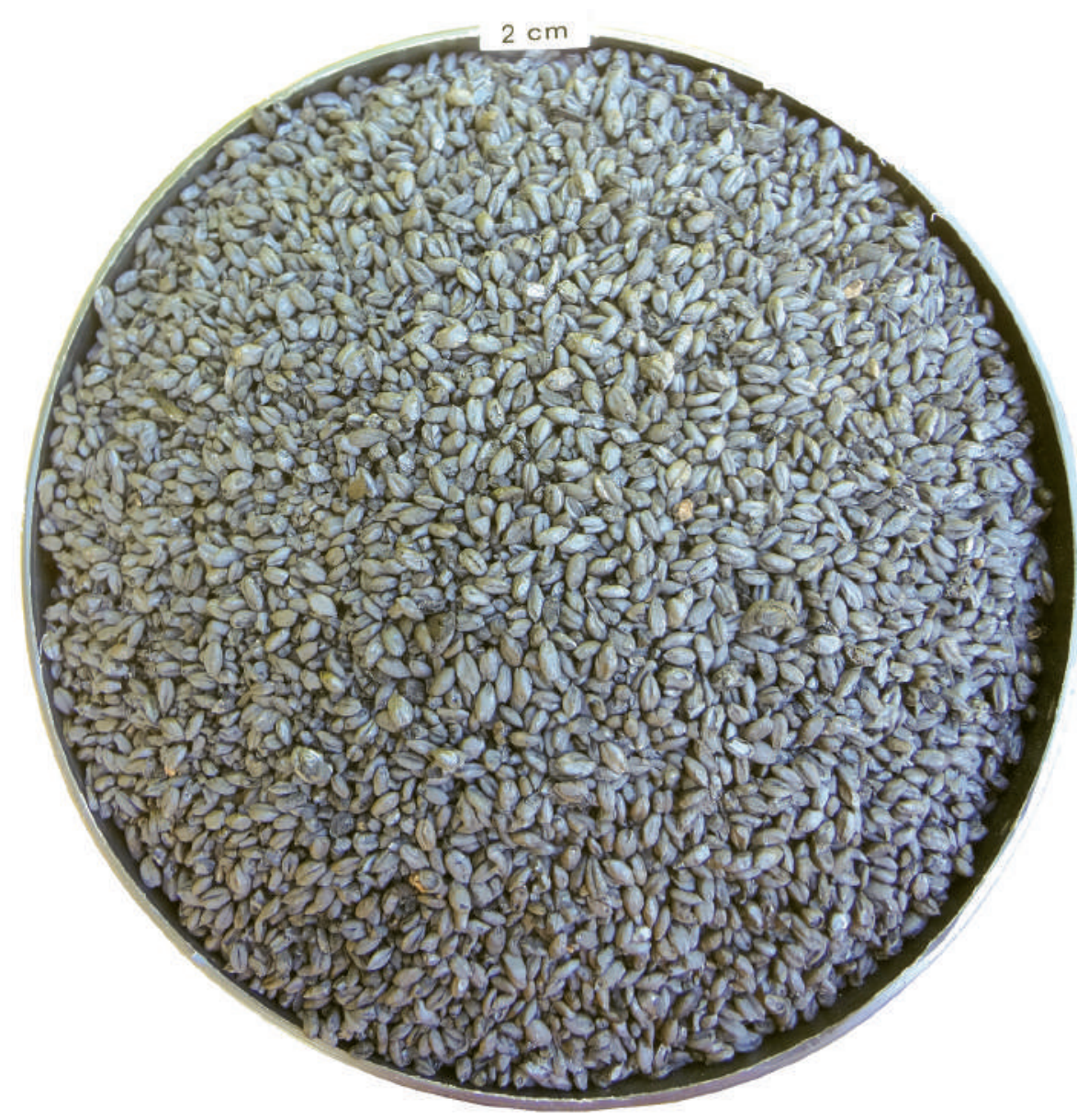

Figure 5. Charred grain mass of naked barley (Hordeum vulgare var. nudum) from the Hârşova-Tell settlement (Gumelniţa culture; exc. 2014, S 1 V, US 30036; by R. Hovsepyan).

Although none of the cultivated plants, wild plants, or weeds recently recovered in Hârşova-Tell are new for the Chalcolithic or Neolithic period of Romania ${ }^{12}$, there are some new records of cultivated plants for the Boian cultural occupation of this settlement: naked barley (Hordeum vulgare var. nudum), bitter vetch (Vicia ervilia), lentil (Lens culinaris) and Timopheev's wheat (Triticum timopheevii) (see Table 1 for the details, the new records are marked with "*”). The hackberry (Celtis sp.) and an essential part of the weedy species are new records for the Gumelniţa cultural occupations of the Hârşova-Tell settlement (Tab. 2, the new records are marked with “*”).

The proportions of the major food and economic groups of our findings are presented in Tab. 4. Although these values do not mandatorily express the exact situation for all investigated communities for every moment of their lives, they may give some preliminary images for their agriculture and vegetal food. No samples with large concentrations of a single plant species, such as grain hoards and threshing waste, were involved in the calculations of Tab. 4. The almost total predominance of a single species crop in the recovered seed hoards may serve an indication that the crop had been harvested carefully avoiding weeds and/or it had been cleaned (e.g. sieved) after the harvest.

Apparently, cultivated cereals had primary importance as a vegetal food and in the agriculture at the settlement; the portions of the cereals are between $95-99 \%$ for all three cultures, and the pulses are consequently less than $5 \%$. The proportions of the cultivated cereals, wheats and barley, are very similar for all the investigated cultures, ca. wheat $85-89 \%$ and barley $11-15 \%$. The portions of the edible fruits and seeds gathered from the wild are less than $1 \%$ for the Boian and Gumelniţa culture samples (Tab. 4).

The systematic and continuous archaeobotanical investigations of the Hârşova-Tell site enrich our knowledge about the Chalcolithic plant economy, agriculture, vegetal diet and household of the site and thus will contribute to the study of the prehistory of the Romanian plain.

$\overline{12}$ Cârciumaru 1996, 2000; Monah 2000, 2005, 2007b; Schier, Draşovean 2004; etc. 
Table 4. Proportions of the main food and economic groups of plants according to carpological material recovered from the Hârşova-Tell site and combined by cultural attribution.

\begin{tabular}{|c|c|c|c|c|}
\hline \multicolumn{2}{|l|}{ Culture } & Boian & Gumelniţa* & Cernavodă I \\
\hline \multicolumn{2}{|l|}{ Sediment volume (liter) } & 573 & 2,029 & 1,158 \\
\hline \multicolumn{2}{|l|}{ Findings of carpological material (units) } & 1,475 & 2,447 & 209 \\
\hline \multirow{2}{*}{$\begin{array}{l}\text { Concentration of carpological material } \\
\text { (units/liter) }\end{array}$} & All & 2.8 & 1.2 & 0.2 \\
\hline & $\begin{array}{l}\text { Cultivated } \\
\text { plants }\end{array}$ & 2.5 & 0.9 & 0.2 \\
\hline \multicolumn{2}{|l|}{ Cultivated plants $/$ All $=$} & $96.1 \%$ & $75.2 \%$ & $95.7 \%$ \\
\hline \multicolumn{2}{|l|}{ Cereals $/$ Cultivated plants $=$} & $98.4 \%$ & $98.6 \%$ & $95.0 \%$ \\
\hline \multicolumn{2}{|l|}{ Wheat $/($ Wheat+Barley $)=$} & $84.9 \%$ & $88.6 \%$ & $85.2 \%$ \\
\hline \multicolumn{2}{|l|}{ Barley $/($ Wheat+Barley $)=$} & $15.1 \%$ & $11.4 \%$ & $14.8 \%$ \\
\hline \multicolumn{2}{|l|}{ Pulses / Cultivated plants $=$} & $1.6 \%$ & $1.4 \%$ & $5.0 \%$ \\
\hline \multicolumn{2}{|l|}{ Gathered** plants $/$ All $=$} & $0.4 \%$ & $0.7 \%$ & $0 \%$ \\
\hline \multicolumn{2}{|l|}{ Weeds $/$ All $=$} & $3.5 \%$ & $24.8 \%$ & $4.3 \%$ \\
\hline
\end{tabular}

* - No samples with large concentrations of single plant species are counted in this table (also the concentration of more than one thousand spikelet bases from oven US1156 shown in Tab. 2).

** - Edible fruits and seeds that possibly were gathered for food.

\section{Conclusions}

Populations of the Chalcolithic Boian, Gumelniţa and Cernavodă I cultures at Hârşova have been practicing agriculture mostly based on the cultivation of cereals and partly on pulses. As elsewhere in the Chalcolithic period SE Europe, the main cultivated plants were einkorn, emmer, bread wheat (spelt and free-threshing varieties), Timopheev's wheat, bitter vetch, small-seeded lentil and pea. Possibly viticulture was practiced as well (at least for the Gumelniţa culture). The gathering of edible fruits, berries and nuts (grape, water caltrop, cornelian cherry, hackberry and plum) was one of the ways to supplement the populations' vegetal food for all the above-mentioned cultures.

\section{Acknowledgements}

This study has been done under the framework of the research program IDEI (PN-II-ID-PCE-2011-3-0982): Landscape and human co-evolution patterns in the wetland area of Balta Ialomiţei", Romania and "Programme de coopération archéologique franco-roumain". The authors express their gratitude to the excavating archaeologists I. Cernău and C. Cernea for proper sampling of the studied sediments.

The Cernavodă I sediment samples and a part of the Gumelnița samples were studied by R. Buxo (excavations of 1993-1995), while the Boian samples and another part of the Gumelnița samples were studied by R. Hovsepyan (materials from the excavations started from 2008 to the present and some samples from the earlier excavations were processed mostly by R.H. in the archaeological base of Popina Borduşani, and partly by local workers in the archaeological base of Hârşova-Tell). 


\section{REFERENCES}

Cârciumaru 1996

Cârciumaru 2000

Galbenu 1962

Jacomet 2006

Marinescu-Bîlcu, Cârciumaru 1992

Monah 2000

Monah 2005

Monah 2007a

Monah 2007b

Popovici 2010

Popovici et al. 2000

Popovici et al. 2001

Popovici et al. 2014

Schier, Draşovean 2004

Zohary et al. 2012
Cârciumaru, M., Paleoetnobotanica, Studii în preistoria şi protoistoria României (Istoria agriculturii din România) [Palaeoethnobotany, Researches in the praehistory and the protohistory of Romania (History of agriculture in Romania)], Iaşi, Helios, 1996.

Cârciumaru, M.. Neolithic palaeoethnobotany of Romania, Cercetări Archeologice, 11(2), 2000, 577-581.

Galbenu, D., Așezarea neolitică de la Hârșova, Studii şi cercetări de istorie veche, 12(2), 1962, 285-304.

Jacomet, S., Identification of cereal remains from archaeological sites, 2nd ed., Basel: Basel University. (Accessed December 30, 2015) https://ipna.unibas.ch/archbot/pdf/ Cereal_Id_Manual_engl.pdf, 2006.

Marinescu-Bîlcu, S., Cârciumaru, M., Colliers de Lithospermum purpureo-coeruleum et de „perles” de cerf dans le contexte Central et Sud-Est Europeen, Prehistoire Europeenne, 2, 1992, 70-88.

Monah, F., Rapport préliminaire sur les macrorestes végétales du Complexe ménagere 521 - le tell énéolithique Hârşova (dép. de Constanza), Cercetări Arheologice, 11(1), 2000, 66-74.

Monah, F., Analiza macroresturilor vegetale din stațiunile calcolitice de la Luncavița și Isaccea, Arheologia Moldovei, 28, 2005, 357-362.

Monah, F., Nouvelles déterminations archéobotaniques pour la Romanie, Arheologia Moldovei, 30, 2007, 333-342.

Monah, F.. The spread of cultivated plants in the region between Carpathians and Dniester, 6th/4th millennia BC, in S. Colledge S., Conolly J. (eds.), The origin and spread of domestic plants in Southwest Asia and Europe, Walnut Creek, Ca, Left Coast Press, 2007, 111-125.

Popovici, D.N.. Copper Age traditions North of the Danube River. In The Lost World of Old Europe. The Danube Valley, 5000-3500 BC: 90-111, New York, P.U.P., 2010.

Popovici, D., Randoin, B., Rialland, Y., Voinea, V., Vlad, F., Bem, C., Haită, G., Les recherches archeologiques du tell de Hârșova (dep. de Constanța), 1997-1998, Cercetări Arheologice, 11(1), 2000, 13-124.

Popovici, D., Randoin, B., Rialland, Y., Le tell néolithique et chalcolithique d'Hârşova (Roumanie), in Guilaine J. (ed.), Communautés villageoises du Proche-Orient à l'Atlantique (8000-2000 avant notre ère), Paris, Éditions Errance, 2001, 119-152.

Popovici, D.N., Randoin, B., Cernău, I., Cernea, C., Ilie, A., Haită, C., Bălăşescu, A., Radu, V., Mărgărit, M., Niţu, L. and Hovsepyan, R., Programul de colaborare românofrancez de la Hârşova-tell, jud. Constanța. Campania 2013. Cercetări Arheologice 21, 2014, 25-54.

Schier, W., Draşovean, F., Vorbericht über die rumänisch-deutschen Prospektionen und Ausgrabungen in der befestigten Tellsiedlung von Uivar, jud. Timiş, Rumänien (19982002), Praehistorische Zeitschrift, 79, 2004, 145-230.

Zohary, D., Hopf, M., Weiss, E., Domestication of Plants in the Old World, $4^{\text {th }}$ edition, New York, Oxford University Press, 2012.

\section{LISTA ILUSTRAŢIILOR}

Figura 1. Localizarea sitului Hârşova-tell pe harta României.

Figura 2. Planul săpăturilor din situl arheologic Hârşova-tell (autor Mihai Florea). 
Figura 3. Grupare de resturi de orz carbonizat în locuinţa SL 302 de la Hârşova-tell şi poziţia ei stratigrafică pe profilul estic al Sondajului I vest (săpături 2014; autor D.N. Popovici).

Figura 4. Descoperiri arheobotanice din contexte ale culturii Boian şi culturii Gumelniţa din situl arheologic Hârşova-Tell (autor R. Hovsepyan). 1-4 - grăunţe carbonizate de alac, 2-3 - alac cu un singur bob (Triticum monococcum), 4 - grâul lui Timopheev (Triticum timopheevii), 5 - bază de spiculețe de alac, 6 - bază de spiculeţ de grâu Timofeev, 7-12 - grăunţe carbonizate de emmer (Triticum dicoccum), 8-10 - grăunţe din aceleași spiculeţe, care rămân ataşate după ce glumele de spiculeţe au căzut, 13 - grăunţe carbonizate de grâu spelta (Triticum aesticum ssp. spelta),14-18 - grăunțe carbonizate de orz nud (Hordeum vulgare var. nudum), 19 - semințe carbonizate de măzăriche (Vicia ervilia), 20 - sămânţă carbonizată de mazăre comună (Pisum sativum), 21 - sămânţă carbonizată de linte (Lens culinaris), 22 - parte carbonizată din sămânţă de colţul-babei de apă (Trapa natans), 23 - sămânţă carbonizată de corn (Cornus mas), 24 - sămânţă biomineralizată de Lithospermum purpurocaeruleum cioplită în partea de sus și în partea de jos pentru a face o mărgea.

Atribuire culturală: 1-13, 15, 17, 20-24 - Boian (săp. 2013), 14, 16, 18-19 - Gumelniţa (săp. 2014). Localizarea eșantioanelor: 1-4 - SC/pP, St. 20, US 20646, SL 109, D3; 5-6 - SC/pP, St. 20, US 20246, C 2065, B3; 7-12 - SC/ pP, St. 20, US 20646, SL 109, C3-D3; 13 - SC/pP, St. 20, US 20247, C 2065, C 1; 14, 16, 18 - S I V, US 30036; 15, 17, 20-22, 24 - SC/pP, St. 20, US 20170, C 2065, D 1; 19 - S I V, US 30045; 23 - SC/pP, St. 20, US 20246, C 2065, A 1).

Figura 5. Masă de grăunţe carbonizate de orz nud (Hordeum vulgare var. nudum) din aşezarea Hârşova-tell (cultura Gumelniţa; săp. 2014, S I V, US 30036; autor R. Hovsepyan).

Tabelul 1. Materialul arheocarpologic din nivelurile culturii Boian de la Hârşova-tell (campaniile de săpături 2013 și 2016, Zona SC/pP, Sector 20).

Tabelul 2. Materialul arheocarpologic din nivelurile culturii Gumelniţa de la Hârşova-tell.

Tabelul 3. Materialul arheocarpologic din nivelurile culturii Cernavodă de la Hârşova-tell.

Tabelul 4. Raportul principalelor grupe de plante utilizate ca hrană şi economice, conform materialului carpologic recuperat din situl Hârşova-tell, combinate cu atribuirea culturală.

ROMAN HOVSEPYAN, Institute of Archaeology and Ethnography NAS, Yerevan, Armenia, roman.hovsepyan@gmail.com

RAMON BUXÓ CAPDEVILA, Museu d'Arqueologia de Catalunya - Girona, Spain, rbuxo@gencat.cat DRAGOMIR-NICOLAE POPOVICI † 